\title{
石油工業における発光分光分析
}

\author{
原明*
}

Emission Spectrographic Analysis in the Oil Industry

\section{Akira HARA}

(Idemitsu Kosan Co., Ltd.)

\section{1. 緒言}

石油工業，とくに精製と製品利用の部面において無機 分析の必要はひん繁に起り，発光分光分析は活用の段階 に入つた，定性分析の目的のみに使用しても確かに重宝 な分析手段ではあるが，定量分析にまで活用できるなら ば，実用価值としても倍加されること注事実である。し かしながら，いわゆる機器分析の一環というらもりで定 量発光分光分析定行扔うと专るとき——くに油や触媒 を取扱おうとするとき-一いかなる形式で試料を導入す るか、いかなる励起光源它選び，いかなる標準試料を用 いるか，あるいは元素のマトリックス効果抑制のために 何を添加し，何を内標準に選定すべきか，等々分析者は 予想外に厄介な問題に遭遇し，乙かも一つの方法が限ら れた種類の試料のみにしか適用できないことを知つて， 次第に本法の実用性に疑念を抱きはじめるに違いない。 化学定量分析は結局湿式分析に頼るべきで, 発光分光分 析は定性分析に止めておくのが賢明なのではなかろうか 之.

われわれはこれに対する回答它得えとする目的で，石 油工業の分野において試みられている分光分析の方法军 実用上の観点から回顧してみた。 そして終りにこの問題 に対する愚見と今後の検討方向とについてつけ加えた.

2. 総 説

石油工業に関する機器分析で発光分光分析が引用され だしたのは大体 1944 年頃からのようである ${ }^{13)}$. 石油

* 出光興産株式会社德山製油所研究所

1) W.H. Naylor, J. Inst. Petroleum, 30, 265 (1944).

2) F. Gill and R.R. Gordon, Petroleum (London) 8, 186 and 212 (1945).

3) S.C. Fulton and J.J. Heigl, Instruments 20, 35 (1947).
の研究室で, 油, スラッジ，グリースあるいはアルカリ， 添加剂，金属などを必要に応じて定性，半定量あるいは 定量する方法について Gulf Research の R.G. Russe11 ${ }^{4}$ と Socony-Vacuum の H.K. Hughes ら5)が述べてい る. Gulf Oil の P.D. Foote ${ }^{6)}$ 注採油, 精製, 製品使用 開発の三部面における発光スペクトルについて概説し, ルーマニヤの N.S. Stirimin ${ }^{7}$ は石油工業における発光 ・吸収・赤外・質量スペクトルに言及している。最近で は, British Petroleum 社の H. Powell ら $5^{8)}$ が石油の 微量化学分析の傾向を論じている. A.J. Ham, J. Noar および J.R. Reynolds ${ }^{91}$ は石油中の金属分析の直接法 四種を比較しているが，この内の一人 J. Noar は Institute of Petroleum Review 誌上飞 Some Notes on the Uses of Emission Spectrography in the Petroleum Industry と題して分光分析の方法 ${ }^{10)}$ と石油 分析 ${ }^{11} の$ 二部作を載せている. これは多分に論評的な総 説で, 発光分光分析の特長を巧夕に表現している.

また，石油工業のみに限つたことではないが，A.S.T. M. から 1920-1950 年の分光化学分析の交献索引仿

4) R.G. Russell, Anal. Chem., 20, 296 (1948).

5) H.K. Hughes, J.W. Anderson, R.W. Murphy and J. B. Rather Jr., Proc. Am. Petroleum Inst. III, 29 M, 89: Discussion 102 (1949).

6 ) P.D. Foote, J. Opt. Soc. Am. 42, 886 (1952).

7) N.S. Stirimin, Petrol Si Gaze 7, 430 and 485 (1956).

8) H. Powell and W.H. Thomas, J. Inst. Petrol. 44, 19 (1958).

9) A. J. Ham, J. Noar and J. R. Reynolds, Analyst, 77, 766 (1952).

10) J. Noar, Inst. Petrol. Rev. 9, 187 (1955).

11) Ibid, 9, 209 (1955).

12) W.F. Meggers and B.F. Scribner, "Index to the Literature on Spectrochemical Analysis" Part I 1920-1939 Part II 1940-1945 Part III 1946 -1950. Am. Soc. Testing Materials, Phil., Pa. 
出版されていることは有益である. A.S.T.M. の発光分 光分析法 ${ }^{13)}$ 正漸次充実してきて打り, 共通事項としては 参考となる点が多いが，石油については然料油中のナト リウム它炎光光度計で分析する方法14) 㦄つているほか，ディーゼル車の使用潤滑油中の摩耗金 属の定量法について種々の Suggested Method ${ }^{15 〜 22) ~ か ゙ ~}$ 提示されている段階であり，これら諸法の審議や燃料油 一般の分析法, 各種触媒の分光分析法はまだまだ今後の 間題である.

\section{3. 原油, 燃料油および添加剤}

\section{1 原油中の金属成分と精製工程}

原油を点火燃燒し，更に電気炉などで炭素を除去すれ 壮灰分が得られる。灰分收率は原油の産地によつて異 り,メキシュ原油の $0.72 \%$ といら高收率のもの㣻ら心゙ ネゼラサンノーキンの様に $0.0005 \%$ しかないものもあ るが，大体 $0.001 \%$ から $0.1 \%$ の間であるととが普通 である。

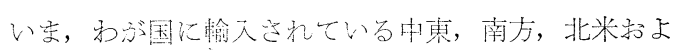
びソ連原油の一部努選びこ秃らの扊分中の金属元素定示 它と Table 1 の通りである.

灰の主成分汇 $\mathrm{Na} 2 \mathrm{O}$ 分 $\mathrm{V}_{2} \mathrm{O}_{5}$ 分であるととが大部分 である坊，稀れ飞 $\mathrm{Fe}_{2} \mathrm{O}_{3}$ や $\mathrm{NiO}, \mathrm{SiO}_{2}$ のとともある。

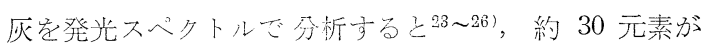
検出される。大部分壮 Table 1 に含まれるが，特殊な 元素としては, Au, Ag, As (オハイオ, 第1 バクー) やサンラフォエル原油中の放射性Uなど27)方ある.

原油はセットリングにより一応の塩水分学除いてから 精製工程にまわされる。近代的な製油所では，この原油 岩デソルターにかけて更に塩分（主にナトリウム分）を 除いてから常圧蒸留と減圧蒸留にかける。乙の際金属成 分のほとんど全部は釜残中に残るから．金属元素分析の 対照としては原油と残油（residual oil）注同義と夕な すことが出来る。

一部の $\mathrm{V}$ と $\mathrm{Ni}$ はポルフィリン錯塩として原油中に 溶存し, 真空蒸留軽油留分には, 僅かながら混入して行

Table 1. 原油中の金属元素*

\begin{tabular}{|c|c|c|c|c|c|c|c|c|c|c|c|c|c|c|c|c|c|c|c|c|c|c|c|}
\hline \multicolumn{2}{|c|}{ 産 } & \multicolumn{3}{|c|}{ 地 } & \multirow{2}{*}{ 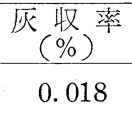 } & \multirow[b]{2}{*}{ Al } & & \multirow[b]{2}{*}{$\mathbf{B a}$} & \multirow[b]{2}{*}{$\mathrm{Ca}$} & \multicolumn{3}{|c|}{ 検 } & \multicolumn{2}{|c|}{ 出 } & \multicolumn{4}{|c|}{ 元 } & \multicolumn{2}{|r|}{ 素 } & \multirow{2}{*}{\multicolumn{3}{|c|}{ Sr Ti V Zn }} \\
\hline ク & ウ & I & イ & ト & & & & & & $\mathrm{Cr}$ & $\mathbf{C u}$ & $\mathbf{F e}$ & $\mathbf{M g}$ & Mn & Mo & $\mathrm{Na}$ & $\mathbf{N i}$ & $\mathrm{P}$ & $\mathrm{Pb}$ & Si & & & \\
\hline ア & ᄏ & & ビ & 广 & - & Al & & $\mathbf{B a}$ & $\mathrm{Ca}$ & $\mathrm{Cr}$ & $\mathrm{Cu}$ & $\mathbf{F e}$ & $\mathbf{M g}$ & Mn & Mo & $\mathrm{Na}$ & $\mathrm{Ni}$ & $\mathrm{P}$ & $\mathrm{Pb}$ & Si Sn & $\mathrm{Sr} \mathbf{T i}$ & $\mathrm{V} \mathrm{Zr}$ & In \\
\hline イ & & ラ & & ン & 0.005 & Al & & $\mathbf{B a}$ & $\mathbf{C a}$ & $\mathrm{Cr}$ & $\mathrm{Cu}$ & $\mathbf{F e}$ & $\mathrm{Mg}$ & Vin & Mo & $\mathrm{Na}$ & $\mathrm{Ni}$ & $\mathrm{P}$ & & Si Sn & Sr Ti & V & \\
\hline イ & & ラ & & ク & - & Al & & $\mathbf{B a}$ & $\mathbf{C a}$ & $\mathrm{Cr}$ & $\mathrm{Cu}$ & $\mathbf{F e}$ & $\mathrm{Mg}$ & Mn & Mo & $\mathrm{Na}$ & $\mathrm{Ni}$ & $\mathrm{P}$ & $\mathrm{Pb}$ & Si Sn & Sr $\mathbf{T i}$ & $\mathbf{V} \mathrm{Zr}$ & $n$ \\
\hline 七 & & リ & & ア & 0.001 & Al & & $\mathbf{B a}$ & $\mathrm{Ca}$ & $\mathrm{Cr}$ & $\mathrm{Cu}$ & $\mathrm{Fe}$ & $\mathrm{Mg}$ & Mn & Mo & $\mathrm{Na}$ & $\mathrm{Ni}$ & & $\mathrm{Pb}$ & Si $S n$ & Sr Ti & $\mathbf{V} \mathrm{Zn}_{1}$ & In \\
\hline$\Sigma$ & & $ナ$ & & ス & 0.006 & Al & B & $\mathbf{B a}$ & $\mathrm{Ca}$ & & $\mathrm{Cu}$ & $\mathbf{F e}$ & $\mathbf{M g}$ & Mn & Mo & $\mathrm{Na}$ & $\mathrm{Ni}$ & & $\mathrm{Pb}$ & Si $\mathrm{Sn}$ & $\mathbf{T i}$ & $\mathbf{V} \mathrm{Zi}_{1}$ & in \\
\hline ヂ & 工 & & リ & - & 0.01 & Al & B & $\mathbf{B a}$ & $\mathrm{Ca}$ & $\mathrm{Cr}$ & $\mathrm{Cu}$ & Fe & $\mathrm{Mg}$ & Mn & Mo & $\mathrm{Na}$ & $\mathrm{Ni}$ & & $\mathrm{Pb}$ & Si Sn & Sr $\mathbf{T i}$ & $\mathbf{V} \mathrm{Zr}$ & $\mathrm{Zn}$ \\
\hline$\exists$ & - & リ & ン & ガ & 0.002 & Al & B & $\mathbf{B a}$ & $\mathrm{Ca}$ & $\mathrm{Cr}$ & $\mathrm{Cu}$ & $\mathbf{F e}$ & $\mathrm{Mg}$ & Mn & Mo & $\mathrm{Na}$ & $\mathbf{N i}$ & & $\mathrm{Pb}$ & Si Sn & $\mathrm{Sr} \mathbf{T i}$ & $\mathbf{V} \mathrm{Zn}_{1}$ & $\mathrm{Zn}$ \\
\hline 第 & 2 & ハシ & ク & - & 0.006 & Al & & $\mathbf{B a}$ & $\mathrm{Ca}$ & $\mathrm{Cr}$ & $\mathrm{Cu}$ & Fe & Mg & Mn & Mo & $\mathrm{Na}$ & $\mathrm{Ni}$ & $\mathrm{P}$ & $\mathrm{Pb}$ & Si & Sr Ti & $\mathbf{V} Z_{1}$ & $\mathrm{Zn}$ \\
\hline
\end{tabular}

* $3 \mathrm{Amp}$ 交流アーク程度で簡便に検出されるもの. 太字はこの全原油に存在する元素.

13) "Methods for emission spectrochemical analysis", Am. Soc. Testing Materials, Phil., Pa (1957).

14) ASTM D 1318-54 T, p. 749 (1958).

15) Methods for emission spectrochemical analysis, ASTM (Sampling) p. 428 (1957).

16) Ibid, (Ashing) p. 429 (1957).

17) Ibid, (Dish Coking) p. 434 (1957).

18) Ibid, (Electrode Coking) p. 439 (1957).

19) Ibid, (Rotating Disk. Electrode) p. 443 (1957).

20) Ibid, (Rotating Platform Electrode) p. 448 (1957).

21) Ibid, (Rotating Disk with Quantometer) p. 454 (1957).

22) Ibid, (Ashing with Quantometer) p. 457 (1957).
くので, 流動接触分解 (FCC) 装置の原料に用いるとき にはこの留分中の金属が問題となる。 また原油にヒ素化 合物を含芑とき，そのナフサ留分をプラットフォーミン グ・プロセスの原料に用いるときにはやはり問題となる. ガソリンには $\mathrm{Pb}$ の添に $\mathrm{Mn}, \mathrm{P}$ の添加剂を用いる こともある。このようなときに注，原油中の金属とは別

23) F. Heide, Naturwissenschaften, 26, 693 (1938).

24) C.L. Guette1, Petroleum World, 42, 60 (1945).

25) S. M. Katchenkov, Doklady Akad. Nauk SSSR., 67, 503 (1949).

26) Jadwiga Zotnicka, Chem. Anal., 3, 776 (1958).

27) E. Longobardi, N. Florentine and A. Mercader, Anales asoc. quim. argentina, 35, 131 (1947). 
に加鉛工程のチエックなどの意晰で分析が必要となる。 なお，後に述べる潤滑油留分も留出油であるから原油に 含まれる金属の影響はまつたくない。

\section{2 原油, 残油, 留出油の分析}

原油または燃料油㕄化子ることなく直接分光分析它 行つている例としては, Humble Oil の Carlson 小よ びGunn が，炭素電極党熱以試料油に浸漬して引上げて 作る Quenched Electrode に250 V, $10 \mathrm{~A}$ の直流アー

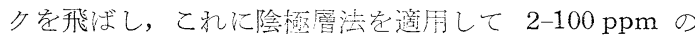
$\mathrm{Fe}, \mathrm{Ni}, \mathrm{Cr}, \mathrm{V}, \mathrm{Ca}, \mathrm{Na}, \mathrm{Si}, \mathrm{Al}$ 最大誤差 $24 \%$ で 分析したもの ${ }^{28}$ がある。 また，同社の Karchmer およ び Gunn は同じく陰極層法で原油中の V, Ni, Al, Fe, $\mathrm{Na}$ なたDesalter charge 中の $\mathrm{V}, \mathrm{Ni}, \mathrm{A} 1, \mathrm{Fe}, \mathrm{Na}$, $\mathrm{Cr}, \mathrm{Si}$ を，またナフサ中の $\mathrm{Cu}$ 定分析している291. 䞟 転ディスク電極法 (Rotating Disk Electrode Technique）で燃料油の分析定行つたのは Richfield Oil 社の Key と Hoggan ${ }^{30}$ である。迴転電極はグラフォイトに 炭酸りチウム定加光て作り，こ秃に然料油，内標準およ びバッファーの混入物を導入乙高压スパークをとばし た. 放電中アークスパーク・スタンドは不活性雾囲気に しておく、標準は, 既知の燃料油に V-oleate, $\mathrm{Ni}-, \mathrm{Na}$-, Ca-2-ethylhexoate のナフサ溶液安加光て作る. バッフ ァーは Ba-2-ethylhexoate である。検出限界は V 2 ppm, Ni $10 \mathrm{ppm}$, Na $0.2 \mathrm{ppm}$, Ca $0.4 \mathrm{ppm}$ であり, 全所要時間 $40 \mathrm{~min}$ であつた. Table 2 および Table 3 にそれぞれ励起条件および重油の分析例を，またFig. 1 に光源装置を示した. Table 3 の試料の金属含有量は 中東重油などに比較すると $\mathrm{Ni}, \mathrm{Ca}$ が多いが，化学分析
に比較して正確度も精度も大差ない加ら，本法怯普通の 燃料油の分析に実用化しらるであるら。ただ， $\mathrm{Ni}$ の感 度が低いこととディスクの製作が咂介であることが難点 である。

銅でディスクを作つて原油，潤滑油などを分析するこ とも最近試みられた られる迴転プラットフォーム電極法 (Rotating Platform Electrode Technique) を燃料油に用い交流スパークを 適用すると微量の $\mathrm{Na}$ までもよく分析出来るとい方れ ๖ ${ }^{32)}$.

Table 2. 励起 - 放電条件

\begin{tabular}{lccc}
\hline 装 & 置 & ARL Precision Source & Unit \\
$\mathrm{C}$ & & 0.007 & $\mu \mathrm{F}$ \\
$\mathrm{L}$ & 360 & $\mu \mathrm{H}$ \\
$\mathrm{I}$ & 8.5 & $\mathrm{Amp}$ \\
強度調節用位置 & $1 / 5$ & \\
透 過 度 & 100 & $\%$ \\
格子シヤッター & 0.3 & \\
予 備 放 電 & 48 & $\mathrm{sec}$ \\
露 & 出 & 12 & $\mathrm{sec}$ \\
ディスク备転速度 & 14 & r.p.m. \\
\hline
\end{tabular}

燃料油の直接分析法は今後とも重要性を增すと考えら れるが，乙かし従来一般㴟化して行つている，扊化の 方法としては，そのまま自然燃焼させ，後炉中で炭素を 酸化除去する乾式法, 硫酸 (硝酸) を使つて酸化する湿 式法と, Ash aid を加えて灰化する Catalytic ashing とある。原油や残油の場合にも湿式灰化法 ${ }^{33}$ を用いる方

Table 3. Bunker C Fuel Oil の分析

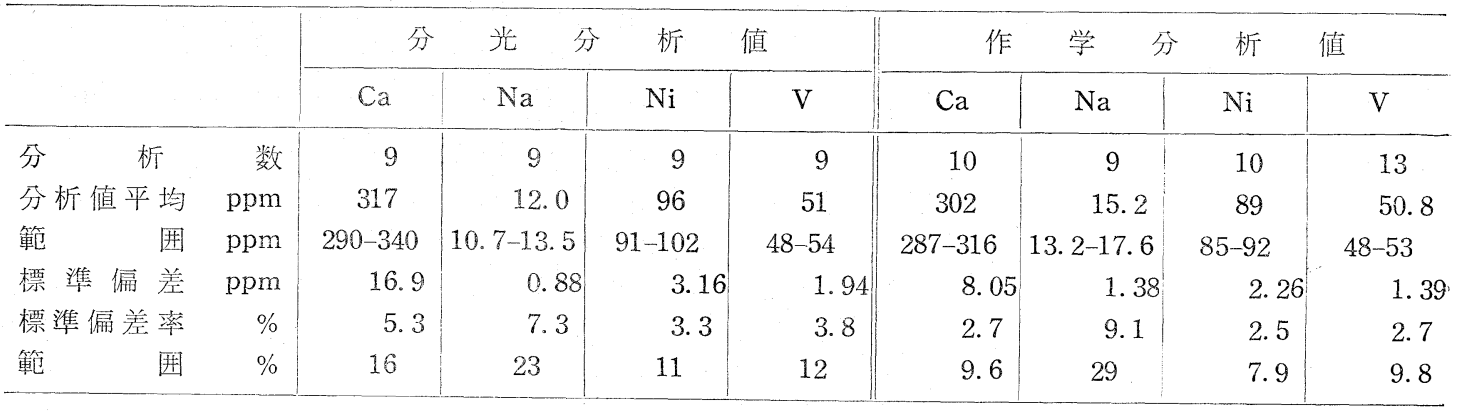

28) M.T. Carison and E.L. Gunn, Anal. Chem., 22, 1118 (1950).

29) J. H. Karchmer and E. L. Gunn, ibid, 24, 1733 (1952).

30) C.W. Key and G.D. Hoggan, ibid, 25, 1673 (1953).
31) Zofia Biernat and Mieczyslaw Solecki (Poland), Biul. Inst. Naftowego, 8, 7, (1958).

32) R. S. Hullings, Appl. Spectroscopy, 12, 139 (1958).

33) K. Nagashima and J. S. Machin, Illinois State Geol. Survey Circ. No. 235, p. 10 (1957). 
もある $3^{34,351}$. Nagashima $5^{331}$ は原油試料安洗滌沪過し た後, 内標準として $\mathrm{Co}\left(\mathrm{NO}_{3}\right)_{2}$ 安加光て湿式灰化し, 後, 塩酸によかして溶液の迴転電極法でアーク学用いてい る.この方法で， $\mathrm{V}, \mathrm{Ni}$ 釜分析することにより米国イリ ノイス原油の同定確認が出来るという36). Anderson ${ }^{34}$ やKanehann ${ }^{35)}$ の方法で经磁性且で 25-50 g 程度を然 やし，マッフル炉で $550-600^{\circ} \mathrm{C}$ 程度で灰化している. 内標準は共に Ti を用い, 分析線対も共に V I $2977.5 \mathrm{~A}$ /Ti I 2956.1 A であつた. Kanehann は対数セクター を用いている。灰に $\mathrm{Co}\left(\mathrm{NO}_{3}\right)_{2}$ の水溶液を加えてよく こね, これを焼いてから炭酸リチウムとグラファイトを 混じ，直流アーク年なたは交流アーク 38)学用いて分析す る方法もある. Dyroff $5^{38)}$ は同時に化学分析も行つて いるが，例えば V の分光分析では標準偏差率が平均約 $8.6 \%$ であり, 原油, 残油のみならず, feed stocks, fireside deposit, engine deposit などにも応用できる という.\&た石油コークス中のバナジウム 70-3700 ppm をZeiss Q 24 で定量した例 39 や，石炭の灰であるが $\mathrm{Sb}$ を内標準として As 25-400 ppm を分析したもの塻米国 25 種の原油圧 ${ }^{41}$ ポーランド 32 種の原油灰 ${ }^{42}$ など ${ }^{431}$ の分 析もある.

高度の緩衝剤孛用いてマトリックス効果学相殺し, 一 Fig. 1. 廻転電極光源装置

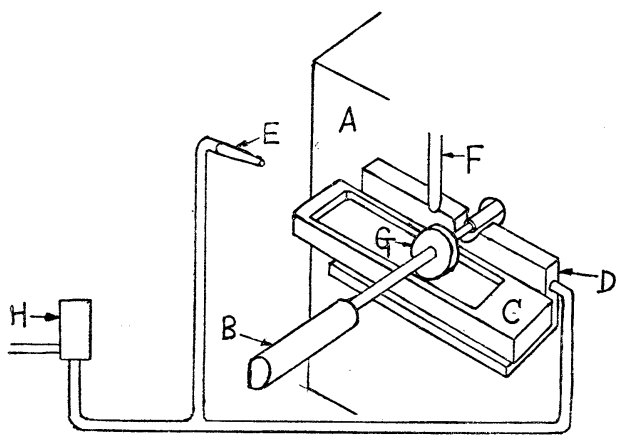

A : Solution excitation apparatus, synchronous motor

B : Brass electrode supporting shaft

C : Sample boat

D : Multiple-orifice argon inlet

E : 0.125-inch nozzle argon inlet

F : 3/16-inch rod electrode

G: 1/2-inch graphite disk electrode

$\mathrm{H}$ : Argon flowmeter

Fig. 2. 趈転ディスク電栖效の良装置

が金属の損失を防ぐ意味では無難である。乙かし長時間 要要するので, 乾式兏化によつても大差ないという報告 般的な分光分析法としてこれらの原油灰やスラッジなど を分析例としたものもある. E. K. Jaycox ${ }^{44)}$ の方法は $\mathrm{CuO}$ と $\mathrm{PbSO}_{4}$ をバッファー兼内標準とし 23 元素を 最良 $\pm 10-15 \%$ の正雄度で分析し，A.J. Frisque ${ }^{45)}$ は $\mathrm{GeO}_{2}$ と黑鉛安用い $\pm 25 \%$ て $\mathrm{Fe}, \mathrm{Ni}, \mathrm{V}$ 是分析, ま

34) J.W. Anderson and H. K. Hughes, Anal. Chem., 23, 1358 (1951).

35) J.A. Kanehann, ibid, 27, 1873 (1955).

36) P.A. Witherspoon and K. Nagashima, Illinois State Geol. Survey Circ. No. 237, 16pp (1957).

37) J.R. Weaver and R.R. Brattain, Anal. Chem., 21, 1038 (1949).

38) G.V. Dyroff, J. Hansen and C.R. Hodgkins, ibid, 25, 1898 (1953).

39) C. Holsky and E. Sclifos, Petrol Si Gaze, 8, 142 (1957).

40) R. H. Hall and H. L. Lovell, Anal. Chem., 30, 1665 (1958).

41) M.C.K. Jones and R.L. Hardy, Ind. Eng. Chem., 44, 2615 (1952).

42) Zbigniew Gregorowicz, Nafta (Poland), 12, 273 (1956).

43) A. C. Smith, J. Appl. Chem. (London), 8, 636 (1958).

44) E.K. Jaycox, Anal. Chem., 22, 1115 (1950).

45) A.J. Frisque, ibid, 29, 1277 (1957). 
た P.V. Mohan ら ${ }^{46}$ 注炭酸りチウムをバッファーとし て 20 元素学 1/2-3/2 の正確度で分析している.

留出油中の $\mathrm{V}$ および $\mathrm{Ni}$ 注揮発性であるから, この 場合の灰化に注意要要する。灰化の際シリカ・アルミ ナなどの ash aid 安入れて金属の散逸学防ぐ方法47,48) がある. この場合の灰化温度は比較的高く $600-700^{\circ} \mathrm{C}$ 学用いている. U.O.P. の Murray らの報告47では直流 アークを用いて標準と比較し, 趈転セクターを用いて分 析した. 正確度は 0.5-2 の因子内であるという。 Esso の L.W. Gamble $\zeta^{49}$ 注 ashing $と$ spectrographic aid として $\mathrm{Mg}\left(\mathrm{NO}_{3}\right)_{2}$ を加え, 更に内標準として Conaphthenateを混じ，また硫酸をむ用いて灰化している。

湿式灰化の方法としては, 試料と略々等容量の硫酸を 加えるのが普通であるが50,51)118)，この他硝酸で酸化する 方法 ${ }^{37}$ もある. Esso の Hansen ら ${ }^{52}$ 注銅粉末をバッフ フー兼内標準とし, 試料, グリセロール, 硫酸を混じて $1000^{\circ} \mathrm{F}$ にて灰化した. 光源は直流アーク $L=50 \mu \mathrm{H}$, :C $=62 \mu \mathrm{F}, R=75 \Omega, 300 \mathrm{~V} 3.2 \mathrm{~A}$ (マルチソース)を 用い, V $3184.0 \mathrm{~A}, \mathrm{Ni} 3414.8 \mathrm{~A}, \mathrm{Fe} 3020.6 \mathrm{~A}$ の分析 線を分光写真器と直読装置とによつて測定した。 0.03$18.5 \mathrm{ppm}$ の $\mathrm{V}$ および 0.5-3.1 ppm の Niを20-25 試料に対し 3/4-1/2 man-hr で分析している.

上記の Gamble らは, 前報531に括いて炭酸リチウム をバッファーとして FCC 張込油灰分の $\mathrm{Fe}, \mathrm{V}, \mathrm{Ni}$, $\mathrm{Na}$ などを分析する方法を述べているが，ここでは灰化 法のことには触れていないようである. その後で留出油 の灰化法の重要性に気付いたものと思われる.

重油扊分中の $\mathrm{Na}$ 分析には炎光法が有効である ${ }^{14)}$. こ れ淔接法ではないから，ベースオイルのタイプや粘度 には全く関係なくなる，金属の干渉としては等重量の $\mathrm{K}, 5$ 倍量の $\mathrm{Fe}, 25$ 倍量の $\mathrm{Ca}$ なでは影響ない. 本法を

46) P.V. Mohan and D.L. Fry, Appl. Spectroscopy, 12, 90 (1958).

47) M.J. Murray and H.A. Plagge, Proc. Am. Petroleum Inst. III 29 M 84 (1949).

48) J.E. McEvoy, T.H. Milliken and A. L. Juliard, Anal. Chem., 27, 1869 (1955).

49) L.W. Gamble and W.H. Jones, ibid, 27, 1456 (1955).

50) O.I. Milner, J.R. Glass, J.P. Kirchmer, A.N. Yurick, ibid, 24, 1728 (1952).

51) J.E. Barney III and G.P. Haight, Jr, Anal. Chem., 27, 1285 (1955).

52) J. Hansen and C.R. Hodgkins, ibid, 30, 368 (1958).

53) L.W. Gamble and C.E. Kling, Spectrochim. Acta, 4, 439 (1952).
6 試料 9 研究室でテストした結果では, Repeatability* は存在量の $13-17 \%$, Reproducibility* 29-38\% であつ た．なお，原油中の $\mathrm{Na}$ を分析する場合には，灰化より も水抽出して炎光測定する方が多くの原油についてはは るかに簡便である54).

ガソリン中の四エチル鉛も炎光光度法で分析され る55,56). Gilbert らの報告 ${ }^{56)}$ とれば， $4058 \mathrm{~A}$ を用い 4020 A のバックグランドで補正し， $0.01 \mathrm{mg} /$ Galon ま で定量している. 本法の特長は現在の ASTM 法 ${ }^{57}$,58) における抽出操作が不要であるため, 分析所要時間が極 めて短いことである。 また，同様に短時間で分析できる $\mathrm{X}$ 線螢光分析および $\mathrm{X}$ 線吸収分析に比較し, 装置がさほ ど高価でないことである. 他方, 欠点としてはベンゼン 溶液の炎光を用いるので引火に気をつけねばならないこ とと, ベースのガソリンのタイプに $\mathrm{Pb}$ の輝度が左右さ れるため, この補正法を考慮しておかなければならない ことである. また最近新しく登場したメチルシクロペン タジェニル・マンガン・トリカーボニルは四エチル鉛に 追加して使用されるが，この Mn も炎光分析で $\mathrm{Pb}$ を求 めるのと同じく $4033 \mathrm{~A}$ の分析線により定量される59.

ガソリンに添加された 5-75 mg/l の P はアルゴン雲 囲気の廻転ディスク電極法で分析出来るという60).この 実験の光源部を Fig. 2 に示す. ディスクからの放熱を よくするためシャフトを二重にしている点と, 多段式, ッズルで試料液表面をアルゴンブローさせている点が従

* Repeatability (反復性) とは, 或る研究窒に打汀る 一人の実験者の測定值の变動性の定量的尺度で, 普 通は短期間に同一装置を用いて行つた測定值につい ていう. 有意差のない二つの值の最大の開きで, 95 \%の probability level にあるもの.

Reproducibility (再現性) とは, 三つの研究室で 別の実験者が得た測定值の変動性の定量的尺度で, 二つの測定值に有意差がないときの両者の最大の開 きをいう。一つ一つの測定值を比べたものでよく， 95\% probability level の必要はない.

上の Repeatability と Reproducibility とを合せ $\tau$, Variability (変動性) と総称する.

54) K.G. Stoffer, Oil Gas J., 56, No. 2, 115: No. 6, 129 (1958).

55) W. Linne and H. D. Wülfken, Erdöl und Kohle, 10, 757 (1957).

56) P.T. Gilbert, ASTM, Spec. Tech. Publ. No. 116, p. 77 (1951).

57) ASTM D 526-56, p. 267 (1958).

58) ASTM D 1269-58, p. 707 (1958).

59) W.S. Garland and A.K. Palmby, Anal. Chem., 31, 1798 (1959).

60) M.E. Griffing, C.T. Leacock, W.R. O'Neill, A.L. Rozek and G.W. Smith, idid, 32, 374 (1960). 
来のものと変つている. 普通は標集偏差 $0.8 \mathrm{mg} / l$ で 30 min で分析分可能であるが，Mn が共存するときに 補正の必要があることと,ベース・ストックの影響はな いが，揮発性の蹸化合物の之きに注幾分低い值になると いう。したがつて添加された憐化合物のタイプが判つて いるときにはいいが，そうでないときに法同じ報交で検 討しているような此色法を採用して沶く方が取市えずは 無難であろう。

\section{4. 潤滑油, 使用油むよび添加剤}

潤滑油中の金属成分の分析には二つの意味がある。一 つは新油の分析で，これは添加戍金属安知ることと，メ ーカーの立場に㧍沙るブレンディングのチェックといら ことである、第二法使用油の分析, すなわ号精製業者自 体の問題というよりも Products development の分野 の問題で亦る. 源加郕の金属は普通 $\mathrm{Ba}, \mathrm{Ca}, \mathrm{P}, \mathrm{Pb}$, $\mathrm{Se}, \mathrm{Si}, \mathrm{Zn}, \mathrm{K}, \mathrm{Na}, \mathrm{Li}$ などである。便用油に含まれ てくる摩耗金属注使用機械の材質に関係が深いが, 大部 分の $\mathrm{Fe}$ の外, $\mathrm{Ag}, \mathrm{Al}, \mathrm{B}, \mathrm{Cu}, \mathrm{Cr}, \mathrm{Mg}, \mathrm{Pb}, \mathrm{Si}$, $\mathrm{Sn}, \mathrm{V}$ などである。

\section{1 新油の分析}

新油の分析法として普通あげられるのは, Quenched Electrode 法, Porous Cup 法, Rotating Disk Electrode 法であり,この他灰化法も勿論使われる.

Quenched Electrode 法については燃料油の処でも台 よつと触れたが, $2^{\prime \prime} \times 0.25^{\prime \prime} \phi$ 程度の炭素棒を赤熱してお き試料油中に浸漬するもので, 引上げてから沪紙でふき, スパーク, 高周波スパークあるいはマルチソースにて放 電させる。本法法 1940 年 Calkins とWhite ${ }^{61,62)}$ が提 示してから直接法として注目をあび, Gulf の Clark, Standard Oil の Baldeschwieler, Ethyl 社の Gambrill, Atlantic Refining $の$ Headington, Texas 社の Levin, Humble Oil の Powers, Socony Vacuum の Rather よりなる A.P.I. の分光分析委員会で協同研究課題と乙 て取上げられ, サンプリング, 励起, 黑度測定, 標準化 法, 検量法などにつき検討され, 実際の照合試験の結果 $\mathrm{Ba}$ の標準偏差率 6-15\%, 正確度 9.3-29.4\%, P の標 準偏差率 2.9-7.9\%, 正確度 6.2-19.9\% という誤差で 分析された ${ }^{631}$.

61) L.E. Calkins and M.M. White, Natl. Petroleum News, 38, No. 27, R 519-30 (1940).

62) - -, Proc. Am. Petroleum Inst., 26, (111), 80 (1946).

63) R.O. Clark et al., Anal. Chem., 23, 1348 (1951).
1949 年 C. Feldman が行つた溶液の Porous Cup

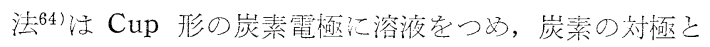
の間に放電されるもので, 放電による熱で試料溶液が多 孔性な炭素電極の底定浸透し, 放電帶飞試料召散給され る.とれ注石油の分析にも応用できるであるうと考えら れたが，Gassman 叔よび O’Nei1165) や Gambrill,

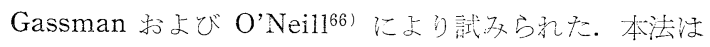

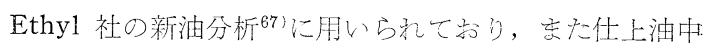
の添加剂の100-500 ppm のP芝本法で分析した例[88も ある.

さて，以上の二法法新油の多にしか䝵用出来ないるの で，店用範囲が限定されている。洞滑油の分析に用いら れる諸法化影響导る因子の関係を Table 4 に示守。× は影響寺る因子というだけの意味であつて, 普通法その 影響安可及的に小さくするような力法を選ぶのである。

Quenched Electrode 法法粘度の影留流少いが, ベース。 オイル, 添加剂の種類やタイプによつて左右されるので, ベースオイルや添加戍崖知つているメーカーだけが用い 得る. Porous Cup 法はベースオイルと添加剂の種類の 影響が少いので, 粘度老整えれば新油の一般法とはな る. しかし, この場合の再現性は電極の Floor thickness. に大きく左右さ秃ることに注意しなけ秃ばならない。

Quenched Electrode 法も, Porous Cup 法も共に油の, 炭素中への浸透利用する所為か，実駼的にも使用油の 分析に法用い得ない. Porous Cup 法では 1 ミクロン以 上の精子は普通通さないといわれる。

Table 4. 各因子の影響

\begin{tabular}{|c|c|c|c|c|}
\hline 方 & \multicolumn{4}{|c|}{ 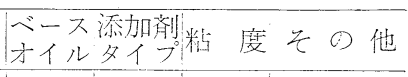 } \\
\hline Quenched Electrode & $x$ & $\times$ & 0 & \\
\hline Porous Cup & 0 & 0 & $x$ & 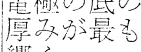 \\
\hline Rotating Disk & 0 & $\triangle$ & $O \times$ & \\
\hline Rotating Platform & $x$ & $\triangle$ & 0 & \\
\hline Flame & $x$ & $\triangle$ & $x$ & \\
\hline Ashing & 0 & $O \triangle$ & 0 & \\
\hline
\end{tabular}

$\bigcirc$ 影響せず， $\triangle$ 普通注影響せず， $\times$ 影響する、二 つあるのは報交による。

現在の処利点の最も多いの惊や法り Rotating Disk

64) C. Feldman, ibid, 21, 1041 (1949).

65) A.G. Gassman and W.R. O'Neill, ibid, 21, 417 (1949).

66) C.W. Gambrill, A.G. Gassman and W. R. O'Neill, ibid, 23, 1365 (1951).

67) EAM (Ethyl Analytical Methods) 23-54.

68) E.L. Gunn, Anal. Chem., 26, 1895 (1954). 
Electrode 法66,69 74) であろう. 光源の装置は Fig. 10 ものと同じである。燃料油中の分析元素は V 10-300 $\mathrm{ppm}$ 程度であつた。潤滑油の場合には， $\mathrm{Ba}$ 少よび $\mathrm{Pb}$ 100-25, 000 ppm, Fe 10-3,000 ppm, P, Ca, Zn 100$\left.2,000 \mathrm{ppm}^{66}\right)$ であつて大体 1 けた高い濃度である。この ため潤滑油に晾ける廻転電極法の場合には, 特に感度向 上を考えてディスクに炭酸塩などを加える必要なく、す べてグラフォイトのディスクを用いている. Ethyl社の Gambrill らの報告 ${ }^{66)}$ によると, 油試料を磁性の燃燒ボ 一トに入れて $15 \mathrm{rpm}$ の趈転電極丧つけ， $45^{\circ}$ のグラフ フイト対極と $3.175 \mathrm{~mm}$ のギャップをへだてて $\mathrm{C}=$ $4 \mu \mathrm{F}, \mathrm{L}=100 \mu \mathrm{H}, \mathrm{R}=5 \Omega$ のマルチソースで放電する. 装置は ARLの $2 \mathrm{~m}$ 格子分光器でスリット $50 \mu$ で予 備放電 $60 \mathrm{sec}$, 露出 $90 \mathrm{sec}$ である. Pb 1-5\% のとき はスパークがよく，また上記の放電条件では $2 \mathrm{~min}$ 放 電しても電極の温度上昇注 $10^{\circ} \mathrm{C}$ 以内で, 分析線とバッ クグランドの比にほとえど变動がないという。また， ディスクの备転速度はある程度速い方がよく，7.5-15 rpm がよい. 雲囲気の問題については, 上記 Gambill らによると, 空気または窒素ガスのジェットは電極を冷 却する効果をもつもので，したがつて，電極が加熱され る条件に沶いては有效であつて分析線とバックグランド の此が一定になるが，そうでない条件のもとでは大差が ないという。しかし, Pagliassotti らの実験69てではPの 定量に䇪素雾囲気定使用乙て精度が $1 / 3$ 向上して扮り， これについて放電中油が酸化されないためであろうとし ている. 油が酸化然焅すれば電極の温度は当然上昇して くるので, 要するに油の着火を防止しながら一定温度に 保つこと法分析精度向上のためには必要な条件のように 思われる。

この迴転ディスク電極法学 $\mathrm{Ca}$ と $\mathrm{Ba}$ の分析法に採用 している所もある. この場合の分析線対はそれ年れ Ca 3933.7/Co 3894.1 および Ba 4554.0/Li 4602.9 であ り，慰酸ガス雲围気中でスパークを用いている。分析 元素が 低濃度 5-60 ppm であるとととディスクの廻転

69) J.P. Pagliassotti and F.W. Porsche, ibid, 23, 198 (1951).

70) Ibid, 23, 1820 (1951).

71) C. W. Key and G. D. Hoggan, ibid, 26, 1900 (1954).

72) D.L. Fry, Appl. Spectroscopy, 10, 65 (1956).

73) 岡田富夫, 中井重夫, 上妻常秀, 分析化学, 5 , 203 (1956).

74) W.D. Perkins, J. R. Miller and J.H. Moser, ASTM Spec. Tech. Publ. No. 214, p. 132 (1957).
速度も遅い（5 rpm）といらことはいささか特異である が, $1 \mathrm{hr}$ の操作で Repeatability は $\mathrm{Ca}, \mathrm{Ba}$ 共に 3 ppm というので良好である。

Table 5. 新油分析における趈転ディスク 電極法の誤差

\begin{tabular}{|c|c|c|c|c|c|}
\hline \multirow[b]{2}{*}{ 元 素 } & \multicolumn{2}{|c|}{ 精 } & \multicolumn{2}{|c|}{ 度 } & \multirow{2}{*}{$\begin{array}{c}\text { 誤 差 } \\
\text { Pagliass } \\
*(70)\end{array}$} \\
\hline & $\begin{array}{c}\text { Gambrill } \\
* *(66)\end{array}$ & $\begin{array}{c}\text { Pagliass } \\
*(70)\end{array}$ & $\begin{array}{c}\text { Rappold } \\
* *(75)\end{array}$ & $\begin{array}{l}\text { Key } \\
*(70)\end{array}$ & \\
\hline $\mathrm{P}$ & 6.2 & 3.3 & 1.4 & & 4.3 \\
\hline $\mathrm{Ba}$ & 10.3 & 2.8 & & 5.0 & 2.3 \\
\hline $\mathrm{Ca}$ & 11.3 & 4.0 & 2.7 & 4.1 & 4.0 \\
\hline $\mathrm{Zn}$ & 8.7 & 4.1 & 1.5 & & 3.4 \\
\hline $\mathrm{Li}$ & & & & 9.2 & \\
\hline $\mathrm{Al}$ & & & & & \\
\hline $\mathrm{Na}$ & & & 5.4 & 3.3 & \\
\hline 平 均 & 9.1 & 3.5 & 2.8 & 5.0 & 3.5 \\
\hline
\end{tabular}

* Average \% deviation

** Coefficient of variation

Table 5 に括いて Gambrill らの実験はかなり精度が 落らているが，これは主に内標準をバックグランドにし たためではなからうかと思われる。 Pagliassotti ら゙01 Mg-2-ethyl hexoate をバッファとし, Niを内標準とし

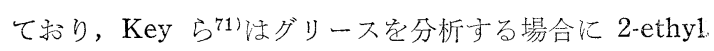
hexoic acid, Strontium 2-ethyl hexoate, Cobalt-2. ethyl hexoate に重質ナフサと醋酸アミルを混じて作つ たグリース状稀䣋剂定用いている，とのときの内標準は $\mathrm{Sr}$ と Coである. この結果肎みてもやはり内標準元素 を用いた方がよいようである。をた Fry ${ }^{72}$ によると， バッファーとして Li-naphthenate, 内標準として Conaphthenate を用い, 光源として活スパークより arclike の方が分析線とバックグランドの比が大きくてよい と述べている. Repeatability 恃存在量の $8.7 \%$ であり， 18ケ月間実際分析定行つて来たといら.

添加剂のメーカーである Oronite 社では, 添加剂の製 造管理, ブレンディング管理, 装置故障および製品ディ ベロプメントのためにカントメーターを用いている75). 試料に稀釈液を加えるが，この中に内標準として dibutyI tin dilaurate を入れておく、こ礼䘮 $5 \mathrm{rpm}$ の迴転ディ スク電極でスパークをとばす。 カントメーターとして ほ，光電子増倍管からの電流をコンデンサーに蓄電した のち、このチャージを記録する方式のものであつた，精 度は Table 5 の通りで, もつともすぐれているが，こ

75) W.A. Rappold and R.E. Ramsay, ASTM Spec. Tech. Publ. No. 214, p. 109 (1957). 
秃は標準試料定作りやすいということと, 写真測光でな くて光電記録式であるというためであるう。なお, 装置 は $70 \pm 2{ }^{\circ} \mathrm{F}$ の温度で相詨湿度 $55 \%$ の部屋に保管して いるという.

㵎滑油中の $\mathrm{Ca}, \mathrm{Ba}, \mathrm{K}, \mathrm{B}$ の分析はまた炎光分析で も行われる76〜78). Table 4 によつてもわかるように, ベースオイルと粘度を考慮しなければならない。また Ca が $\mathrm{P}$ と結合している添加剤のときには, $\mathrm{Ca}$ の輝線 が弱くなる。乙れ以外の $\mathrm{P}, \mathrm{Na}, \mathrm{Zn}, \mathrm{Pb}$ 拈よび $\mathrm{S}$ 注 干渉しない。しかし，ベースオイルと粘度の因子につい ても，サンプルをベンゼンかベンゼンとインプロピルア ルコールとの混合液の大過剩でうすめるので, これらの 影響は普通無視出来る程度となる.

新油に対しても使用油に対しても灰化法は用いられる が， $\mathrm{Pb}$ を含むときには損失をなくするため湿式灰化の 必要がある。兏を水溶液としてからでも, アルカリ金属 や $\mathrm{Ca}, \mathrm{Ba}, \mathrm{Sr}$ などは炎光分光分析を利用してもよい. この場合には, 陽イオンの相互干渉, 塩の浱度, 導入速 度などが分析元素の輝度に如何に影響するかについてあ らかじめ考慮が必要である. これらの点に関しては, 最 近次第に検討されはじめた

\section{2 使用油の分析}

使用油中の摩耗金属の大部分はスラッジと共に油中に 懸濁している．懸潈物と clarified oil と別々に測定する ときには, 炉過または遠心分離によつて分別88)して行う。 乙かし普通浪試料空加温, 攪拌して一様にし, 特別大き なもの以外分離しないままで分析する。この場合に用 いられる力法法灰化法, コークス化法, 電極内の灰化・

76) A.L. Conrad and W.C. Johnson, Anal. Chem., 22, 1530 (1950).

77) L. Moberg et al., ASTM Spec. Tech. Publ. No. 116, p. 92 (1951).

78) B.E. Buell, Anal. Chem., 30, 1514 (1958).

79) 石田良舆, 炎光分光分析 (分光学会 - 分析化学 会) p. 60 (1954).

80）池田重良, ibid, p. 69 (1954).

81）石田泉平，分光研究，4，3 (1956)

82) L. Manna, D.H. Strunk, S.L. Adams, Anal. Chem., 29, 1885 (1957).

83) H. Bode, H. Fabian, Z. anal. Chem., 163, 187 (1958).

84) W.H. Foster, Jr. and D.N. Hume, Anal. Chem., 31; 2028 (1959).

85) Ibid, 31, 2033 (1959).

86) M.R. Baker and B.L. Vallee, ibid, 31, 2036 (1959).

87) K. Fuwa, R.E. Thiers, B.L. Vallee and M.R. Baker, ibid, 31, 2039 (1959).

88) EAM (Ethyl Analytical Methods), 34-54.
コークス化法, 趈転ディスク電極法および趈転プラット

フォーム電極法である.

サンプリング法としては, 使用油の場合は必ず $60 \pm 10$ ${ }^{\circ} \mathrm{C}$ 程度に加温攪挥し，場合によつては 100 目篩のフル イで炉過して十分均一にする必要がある。また，実験操 作中も固形物が沈積しないよう注意が必要である.

灰化はルッボに $20 \mathrm{~g}$ 程度の試料をとって行う.引火 燃焼の後 $538^{\circ} \mathrm{C}$ のマフル炉で炭素除去することも燃 料油の埸合と同様である15)。普通は乾式灰化であるが, $\mathrm{Pb}$ などを主にするとき湿式灰化を用いることもある。 このときに注勿諭酸に $\mathrm{Fe}$ や $\mathrm{Pb}$ を含まないことが必要 である.

灰の分光分析法注常法でよい，標準は合成灰また注分 析ずみの試料を用いる・バッファーには大過剩の $\mathrm{BaSO}_{4}$ と $\mathrm{CaSO}_{4}$ とを用いる ${ }^{16)} .40 \mathrm{~V} 7 \mathrm{~A}$ の直流アーク季た は $5 \mathrm{kV} 2 \mathrm{~A}$ の交流アークを光源とするとよい. I.P.の 方法 ${ }^{89}$ によると, $\mathrm{Fe}_{2}\left(\mathrm{SO}_{4}\right)_{3}$ をフラックスとして試料を ペレットとしたのち銅電極上で直流アークを飛ばしてい

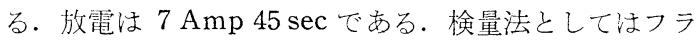
ッスに用いた $\mathrm{Fe} の$ 線との等強線対を用い, $\mathrm{Mg}, \mathrm{Mn}$, $\mathrm{Pb}, \mathrm{Sn}, \mathrm{Si}, \mathrm{W}, \mathrm{Mo}, \mathrm{Ni}, \mathrm{Be}, \mathrm{V}, \mathrm{Ti}, \mathrm{Ag}, \mathrm{Co}, \mathrm{Zn}$, $\mathrm{Cr}, \mathrm{Al}, \mathrm{Ca}, \mathrm{Ba}, \mathrm{Sr}$ 分析している. しかし，この方 法だけではFe が求められないというのは不便である.

Hodgkins $5^{90}$ 法常法で灰化し, $\mathrm{CaSO}_{4}$ とグラファイト を混じ，Co を内標準として $5 \mathrm{kV} 2 \mathrm{~A}$ の交流アークだ Cu 5-500 ppm の分析芫した. 化学分析との差 5.4\%, 標準偏差率 8.5\% であった。 また Gent ら ${ }^{91}$ 将黑鉛と と $\mathrm{CuO}$ と定混じて死化し, 直流アークで $\mathrm{Ba}, \mathrm{P}, \mathrm{Pb}$, Zn を分析した。平均誤差は $110 \%$ であった。

灰化法では，コークスから先に時間がかかるふら，そ 少省略したコークス化法もある。試料に黑鉛とベンゼ ン溶液(バッファーと内標準のため $\mathrm{Ba}$ および $\mathrm{Ni}$ 化合 物学べンゼンにとかしたもの）とを混ぜ， $590^{\circ} \mathrm{C}$ 以下で 燃焼させてコークス状となったものに更にグラファイト を混じたり ${ }^{92)}, \mathrm{BaCO}_{3}$ を混じたり ${ }^{17)}$ て分析試料とす る.この場合の標準は扊化法の場合とほ添同じものに9 倍の黑鉛をまぜて作つている。灰化法とコークス化法之

89) IP (The Institute of Petroleum) $122 / 55 \mathrm{~T}$, p. 544 (1958).

90) C.R. Hodgkins and J. Hansen, Anal. Chenn., 26, 1759 (1954).

91) L. L. Gent, C. P. Miller and R. C. Pomatti, ibid, 27, 15 (1955).

92) R.F. Meeker and R.C. Pamatti, ibid, 25, 151 (1953). 
Table 6. 乍化法とコークス化法の精度比較

\begin{tabular}{c|c|c|c|c|c}
\hline & $\begin{array}{c}\text { Relative } \\
\text { 元 素 }\end{array}$ & $\begin{array}{c}\text { Repeata- } \\
\text { bility } \\
\%\end{array}$ & $\begin{array}{c}\text { Relative } \\
\text { Reprodu- } \\
\text { cibility } \\
\%\end{array}$ & $\begin{array}{c}\text { Relative } \\
\text { Repeata- } \\
\text { bility } \\
\%\end{array}$ & $\begin{array}{c}\text { Relative } \\
\text { Reprodu- } \\
\text { cibility } \\
\%\end{array}$ \\
\hline $\mathrm{Al}$ & 70.1 & 282 & 23.9 & 47.2 \\
$\mathrm{~B}$ & 54.1 & 300 & 23.5 & 74.6 \\
$\mathrm{Cr}$ & 30.3 & 254 & 24.7 & 34.3 \\
$\mathrm{Cu}$ & 38.0 & 233 & 22.1 & 35.0 \\
$\mathrm{Fe}$ & 34.6 & 228 & 18.9 & 62.8 \\
$\mathrm{~Pb}$ & 49.4 & 229 & 19.7 & 96.0 \\
$\mathrm{Si}$ & 58.9 & 245 & 15.8 & 129.0 \\
$\mathrm{Ag}$ & 42.6 & 233 & 18.6 & 110.0 \\
\hline
\end{tabular}

の精度の比較は Table 6 の通りである16,17). これをみ ると, コークス化法はかなりの高精度であることが明ら かであろら.

電極内で扊化する方法 ${ }^{93)}$ もる. 試料に Co-naphthenate の内標準を加えて灰化するが，ミクロバーナーで Fig. 3 の電極を加熱しておき，これに上記試料溶液を滴 下してゆくのである. コークス化の後電極の円筒部を切 り落して $5 \mathrm{kV} \times 2 \mathrm{~A}$ の交流アーク，ギャップ $6 \mathrm{~mm}$ で 放電させるのである.この方法注放電の安定化にはいい が，バッフォーを用いていないので有機燐化合物を含む とき誤差を生じるという．電極をミクロバーナーで加熱 した場合には, 条件が一定しにくいので電気加熱を用い
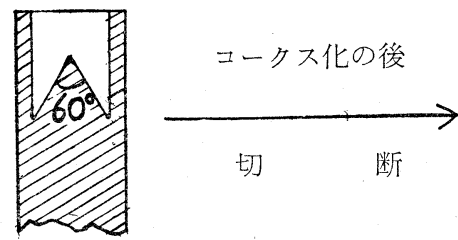

切 断

Fig. 3. Hansen の用いた電極

たのが Barney ら94)である。この場合には灰にまでな りにくいので，いわばュークス化法である。また， Canaphthenate, monodioctyl acid orthophosphate およ び Linseed Oil の混合物をまぜている. 本法法その後 A.S.T.M. の委員会で検討され，一部修正された.すな わ占, 添加物は無水の $\mathrm{CaCl}_{2}, \mathrm{~K}$-naphthenate, monodioctyl orthophosphate となつた. 標準として鉄の懸濁 液を用いるもの $0^{931}$ もるが，A.S.T.M.などは有機金属 化合物を記載している。

93) J. Hansen, P. Skiba and C.R. Hodgkins, ibid, 23, 1362 (1951).

94) J.E. Barney II. and W.A. Kimball, ibid, 24, 1548 (1952).
さて，迴転ディスク電極法については新油の分析の際 記述したが，これは使用油にも勿論使われる191. A.S. T.M.の Suggested Method ${ }^{15 \sim 22)}$ によれば, 光源は低 圧，過制動，直流放電で arc-like の性格をもつものが よく，場合によつては高圧直流スパークで回転ギャップ あるいは空気断続によるスパークも用いる．標準は有機 金属化合物をブレンドして作るが，バッフォーとして organophosphate としての $1,000 \mathrm{ppm} の \mathrm{Ca}$ を大れ， また Co 化合物を内標準のために入れている.

使用油の場合よく使われるいま一つの方法は备転プラ ットフォーム電極法である ${ }^{20,95)}$ ，電極の略図を Fig. 4 (b) に示す. 光源は 2-6 Amp. のトリガー放電 ${ }^{20)}, 3.5$ Amp. の直流アークあるいは交流スパーク95)を用いる. プラットフォームの廻転速度は $10 \mathrm{rpm}$. 程度である. これは一種の電極上コークス化法であつて, $343^{\circ} \mathrm{C}$ の木 ットプレート上ルプラットフォーム電極をおき, 表面を air blow しながら調製溶液 $0.5 \mathrm{~m} l$ を滴下して表面を一 様に coatさせる. 本法の問題点は, 標準試料の問題と木
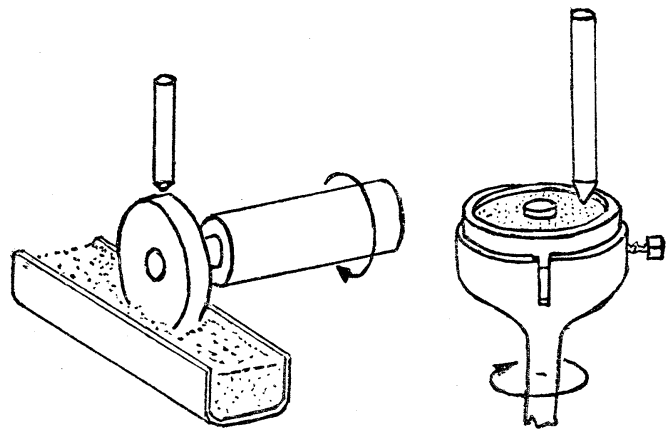

(a) Rotating Disk

(b) Rotating Platform

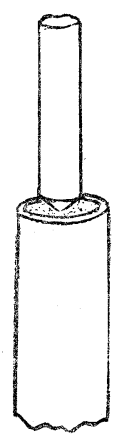

(c) Electrode Coking

(d) Dish Coking and Ashing

Fig. 4. 使用油分析における電極形状

95) J.J. Rozsa and L.B. Zeeb, Petroleum Processing, 8, 1708 (1953). 
ットプレートの温度維持の点であろう、標準と試料のべ 一スオイルが違うときには, 特にこの温度が問題である。

Table 7. 超転ディスク法と趈転プラット フォーム法の精度比較

\begin{tabular}{c|r|r|r|r|r|r}
\hline \multirow{2}{*}{ 元素 } & \multicolumn{3}{|c|}{ Disk } & \multicolumn{3}{|c}{ Platform } \\
\cline { 2 - 7 } & $\sigma_{\tau} \%$ & $\sigma_{\omega} \%$ & $\sigma_{L} \%$ & $\sigma_{\tau} \%$ & $\sigma_{\omega} \%$ & $\sigma_{L} \%$ \\
\hline $\mathrm{Al}$ & 20.6 & 16.6 & 25.3 & 18.0 & 13.1 & 43.7 \\
$\mathrm{P}$ & 12.6 & 13.2 & 14.9 & - & - & - \\
$\mathrm{Cr}$ & 38.0 & 22.1 & 18.8 & 11.7 & 16.5 & 20.4 \\
$\mathrm{Cu}$ & 16.6 & 18.2 & 18.0 & 17.3 & 11.0 & 45.9 \\
$\mathrm{Fe}$ & 12.2 & 9.4 & 9.1 & 12.5 & 11.3 & 36.1 \\
$\mathrm{~Pb}$ & 28.5 & 20.0 & 20.3 & 21.8 & 14.6 & 19.8 \\
$\mathrm{Si}$ & 21.9 & 17.6 & 23.9 & 49.5 & 18.4 & 50.7 \\
$\mathrm{Sn}$ & - & - & - & 14.3 & 11.5 & 85.9 \\
$\mathrm{Ag}$ & 22.3 & 16.9 & 21.7 & 15.7 & 10.0 & 58.0 \\
\hline
\end{tabular}

$\sigma_{\tau}:$ Coefficient of variation $\%$

$\sigma_{\omega}$ : Coefficient of variation for weekly averages $\%$ $\sigma_{L}$ : Coefficient of variation among laboratories \%

A.S.T.M. の Suggested Method ${ }^{19,20)}$ から, 趈転デ イスク電極法と趈転プラットフォーム電極法の精度を引 用して比較してみると Table 7 の通りとなる. Repeatabilityについては雨法に大差ないが，Reproducibilityを みたとき，プラットフォーム法に就ける $\mathrm{Al}, \mathrm{Cu}, \mathrm{Fe}$,

$\mathrm{Si}, \mathrm{Ag}$ 亿問題があるようである.

直読式の分光計による方法も検討されている21,221. 趈 転ディスク電極法の場合まだ多くの実験データーがない が精度は存在量の $\pm 10 \%$ 程度であるうという。直読式 にした場合兏化法の精度は著しく向上している。

以上の外，エンジンの潤滑管理に直接法を適用した 例96,97)や前記 Meeker らの步法を芽いてエンジンの事故 防止老管理する具体的な方法に関主る報告981もるる。鉄 道関係の潤滑管理に怡米国ではすでに活潑に分光分析が 応用さ秃ているよらであり99,1001，をた日本に抽て子 最近国銑で分光分析法等检討しはじめている ${ }^{1011}$.

最後に，各法における检出感度および特長を示可表学 揭げる (Table 8 お よび Table 9 ).

96) K.R. Every, Soc. Chem. Ind. Victoria, 54, 1180 (1954).

97) H. Luther, Erdöl and Kohle, 8, 298 (1955).

98) R. E. Linnard, C. B. Threlkeld and R. T. Blades, Trans. Am. Soc. Mech. Engrs., 79, 709 (1957).

99) V.C. Barth, ASTM. Spec. Tech. Publ. No. 214, p. 140 (1957).

100）金沢寿人（国鉄工作局修車課）米国鉄道で採用中 のスペクトル分析 (昭和 3 年 12 月 2 日報告).

101）金沢寿人，橘芳実，遠山健次郎，山口昇， 分光研究，7，32 (1958).
Table 8. 油中金属の検出感度, ppm

\begin{tabular}{|c|c|c|c|c|c|c|}
\hline 元素 & 分析線 & 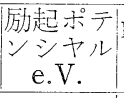 & $\begin{array}{l}\text { Porous } \\
\text { cup }\end{array}$ & $\begin{array}{l}\text { Rot. } \\
\text { Disk. }\end{array}$ & 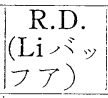 & $\begin{array}{l}\text { Rot. } \\
\text { Plat. }\end{array}$ \\
\hline Co & 2580.372 & 13.83 & & 5 & 10 & \\
\hline $\mathrm{Zn}$ & 3345.02 & 7.75 & 50 & 50 & 50 & \\
\hline $\mathrm{Ca}$ & 3158.87 & 13.11 & 20 & 100 & 20 & \\
\hline $\mathrm{Ca}$ & 3179.33 & 13.11 & & 1 & & \\
\hline $\mathrm{P}$ & 2535.65 & 7.18 & 100 & 40 & 100 & 40 \\
\hline $\mathrm{P}$ & 2554.9 & 7.1 & & 100 & 200 & \\
\hline $\mathrm{Ba}$ & 2335.27 & 11.2 & 200 & 100 & 40 & 10 \\
\hline $\mathrm{Mg}$ & 2790.79 & 16.44 & 0.4 & 0.2 & 0.5 & \\
\hline $\mathrm{Pb}$ & 2833.07 & 4.4 & 50 & 30 & 20 & 2.0 \\
\hline $\mathrm{Cu}$ & 3247.54 & 3. 89 & 2 & 1 & 1 & 0.1 \\
\hline $\mathrm{Fe}$ & 2599.4 & 12.61 & 4 & 3 & 5 & \\
\hline $\mathrm{Al}$ & 3082.15 & 4.00 & 5 & 2 & 10 & 0.1 . \\
\hline $\mathrm{Ni}$ & 2394.52 & 14.44 & 10 & 10 & & \\
\hline $\mathrm{Mn}$ & 2576.10 & 12.19 & 2 & 2 & & \\
\hline $\mathrm{Ag}$ & 3290.68 & 3.76 & & 1.0 & 1.0 & 0.1 \\
\hline B & 2497.724 & 4.94 & & 2.0 & 2.0 & 1.0 \\
\hline $\mathrm{Si}$ & 2881.59 & 5.06 & & 2.0 & 2.0 & 0.5 \\
\hline $\mathrm{Cr}$ & 2835.6 & 12.63 & & 10.0 & 20.0 & 1.0 \\
\hline
\end{tabular}

Table 9. 油の分光分析の特長

\begin{tabular}{|c|c|c|}
\hline 方 法 & 内標準 & 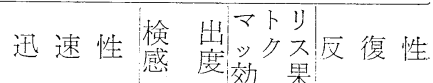 \\
\hline
\end{tabular}

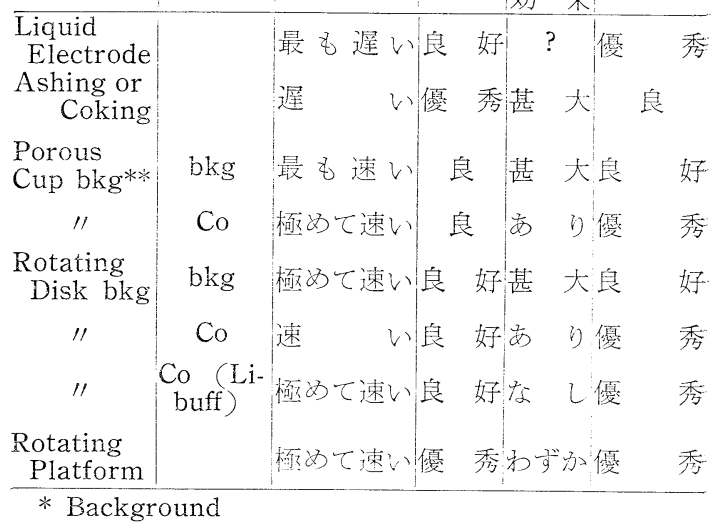

\section{5. 分解・改質触媒}

ここでは F.C.C. 触媒と Platforming 触媒を中心 述べる. Unifining Process に用いるハイドロボン触媒 は一般に金属の污染にさほど敏感でないので省略する。

F.C.C. 触媒注 $\mathrm{SiO}_{2}+\mathrm{Al}_{2} \mathrm{O}_{3}$, プシットフォーミング触媒 ほ $\mathrm{Al}_{2} \mathrm{O}_{3}$ 軍触媒または触媒のベースとしており，これら を使用するとき微量の不純金属成分で污染されてくる. このとき含まれる数 10 ない数 $100 \mathrm{ppm}$ の金属成分炎 定量する問題である. 湿式の化学分析でこれ学行う場合 
には分析元紊を濃縮するのに大変な手間がかかる。これ にひきかえ，分光分析定用いると分析元素の莀度の上か らいつても最適であつて直接法の利点が実際に生きてく る.

\subsection{F.C.C. 触媒}

触媒組成は，例光ば合成触媒に低アルミナと高アルミ ナとあり, $\mathrm{Al}_{2} \mathrm{O}_{3}$ と $\mathrm{SiO}_{2}$ の比注例えば 13:87 25:75 である。これに付着する污染金属の内, 触媒活性它低下 させる金属として普通 V, Ni， Fe, $\mathrm{Cu}, \mathrm{Na}$ が問題と なる、乙れらの実際の濃度範囲は大まかにみて102), それ ぞれ 40-1,600, 10-600, 1,000-14,000, 0.3-60, 703, $200 \mathrm{ppm}$ という程度である。

これに用いる分光分析法として最も普通のものは粉末 アーク法であるう。従来粉末アーク法は高感度ではある が，精度が劣るとされていた．しかしながら．励起の方 法や光源に打ける物理的諸現象定整理考察するとかなり の精度の向上も可能と思わ机る103,1041.

粉末アーク法をほとえどそのままの形で分解触媒に応

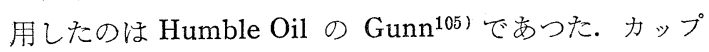
形電極で直径预よび染さ $3 \mathrm{~mm}$ の穴をあけたものに調 製試料をつめ, $250 \mathrm{~V} 12 \mathrm{~A}$ の直流アークを用いた。ギャ ップは $7 \mathrm{~mm}$ である. 分析線対は $\mathrm{Cr} 4254.3 / \mathrm{W} 4294.6$, V 3184.0/Co 3405.1, Ni 3483.7/Co 3474.0, Ca 3179.3/ Sr 3464.6, Fe 3407.5/Co 3405.1, Na 3302. 3/Co 3405.1 で使用分光器は A.R.L.の $1.5 \mathrm{~m}$ 格子分光器であり, スリット10ミクロンである. この場合には放電中試料が は㸚るととがあり，その場合にはやり直すという．三回 の測定值を平均して結果とするが, 標準偏差率注 Fe 8\%, Ca および Na 16\%， Ni 12\%，Cr およびV $5 \%$ であつ

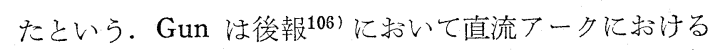
使用触媒中の V, Ni， Fe, Ca, Na おうよび内標準の Co, $\mathrm{Sr}, \mathrm{W}$ の発光特性をしらべ, V, Fe, Co, Na は $10 \mathrm{sec}$ 安 でに最強のスペクトルを示すが， Ca と Sr は $30 \mathrm{sec} に$ 極大值をもつことを示した，との場合の電極は Centerpost 型で穴の深さ $6 \mathrm{~mm}$ ギャップ $3 \mathrm{~mm}$ であって, 前 の実験条件とは異るが，大体において直流アークにおけ る発光特性を示すと考えてよいであるう.

カップ型グラフォイト電極に試料定つめ, 銅の対極它

102) J. J. Blazek and F. H. Macke, Petrol. Eng., 31, C-21 (1959).

103） 中島篤之助, 発光分光分析の諸問題, pp. 11 (1955).

104）酒井昭四郎, 化学技術, 3, 77 (1959).

105) E.L. Gunn, Anal. Chem., 21, 599 (1949).

106) Ibid, 23, 1354 (1951).
使用し交流アークを用いて $\mathrm{Na}$ の文分析した方法107も ある.中型プリズム分光器で $\mathrm{Na} 5890 / \mathrm{Cu} 5218$ の線対 を用いるという。また，主にベントナイトの様な天然触 媒の $\mathrm{Mg}$ 抢よび $\mathrm{Zr}$ 觉直流アークで分析している例108) もある。電極は Center-post 型で, 300-340 V 10 A を 用いている. $\mathrm{Mg} 2871 / \mathrm{Cu} 2769, \mathrm{Zr} 3392.0 /$ Co 3398.8 の線対定使用する。精度，正確度共に Mg $12 \%, \operatorname{Zr} 6 \%$ 程度であった。

試料に塩化アンモン等混じてアークをとばすと，短時 間の内に試料が吹上げられ，アーク柱に導入される。こ れには一種の Center-post 型である Hasler の電極1091 を用いる。この High Velocity Stream Arc 法を分解 触媒に応用したのは Shell Oil 社 Wood Liver Laboratories の R.A. Burdett と C. Jones ${ }^{110)} て ゙$ あた. 触媒 と塩化アンモン等容量と黒鉛を混じて電極につめてアー クをとばし. V 3184 A/Al 2568 A, Fe 2724 A/A1 2568A, Fe 2724 A/Si 2532 A, Ni 3415 A/Si 2532 A, Cu 3274 A/ Si $2532 \mathrm{~A}, \mathrm{Na} 3302.3 \mathrm{~A} / \mathrm{Si} 2532 \mathrm{~A}, \mathrm{Cr} 4254 \mathrm{~A} / \mathrm{Si} 2532 \mathrm{~A}$ の線対空用いて分析している. V の場合湿式分析（ポー ラログラフ法)との差 $\pm 1.4 \%$ で良好な一致を示してい る.な抢，乙の報交で同時に通常の直流アーク法もテス トしているが, バックグランドとの比を用いているため に良好な結果は得られていない。高融点粉末のアーク法 で注, 放電中粉末がは福て電極から出てしまつたり, あ るいはビーズを形成して完全なスペクトルが得にくくな る.この場合に用いた High Velocity Stream Arc 法 は，普通の目的である Carrier distillationの抑制とい うよりもこのビーズ生成を防ぐのに役立つていると思る れる. しかしこの場合には, 試料のアーク柱への導入が 余りに短時間であるために発光が不安定になるというこ とと, 日常分析に塩化アンモンを多用すると光源部が污 れやすいという久点がある.

以上の観点から考えて, 触媒試料についての成型電極 法はかなりよい方法と考光ら机る。 D. Harmon ら ${ }^{111}$ は 20,000 PSI の圧で直径 $0.5^{\prime \prime} \phi$ のペレットを作り。これ を上極とし，下極怯とがらした $0.25^{\prime \prime} \phi$ のグラフォィト 棒定使用した。成型用のバインダー尔よび電気の伝導度 をもたせる意味で, 試料には天然の黑鉛を使用している。

107) J.B. Marling, ibid, 20, 299 (1948).

108) L.W. Gamble, ibid, 23, 1817 (1951).

109) M.F. Hasler, J. Opt. Soc. Am., 31, 140 (1941).

110) R.A. Burdett and L.C. Jones, Anal. Chem., 19, 238 (1947).

111) D. Harmon and R. G. Russell, ibid, 23, 125 (1951). 
励起には高压スパークを用いている. 分析線対は, Fe I $2970.1 \mathrm{~A} / \mathrm{Si}$ I 2970.3 A, VII 3102.3/Si I 2970.3 A, Na I 3302. $3 \mathrm{~A} / \mathrm{Si}$ I 2970. $3 \mathrm{~A}$, Ni I $3414.7 \mathrm{~A}$, Ni I 3414.7A/ Si 2970.3 A, Na I 5886.9 A/Li I 6707. 8 A であり, 標 準偏差率で V 7.4\%, Ni 9.1\%, Fe 1.5\%（化学分析 $0.64 \%), N a 7.4 \%$ であつた。

Weaver ${ }^{37)}$ やDyroff ${ }^{38)}$ が油学分析した場合と同じよ うに炭酸りチウムをバッフォーとし，コバルトを内標準 とするシリカ・アルミナ触媒の分析については Key と Hoggan $^{112)}$ が行つている. この実験では, 触媒を $1050^{\circ} \mathrm{F}$ $2 \mathrm{hr}$ 焼いてからコバルト, 炭酸リチウム, 黑鉛を混じ, 100,000 PSI の圧力で趈転ディスクを成型し， C= $0.007 \mu \mathrm{F}, \mathrm{L}=360 \mu \mathrm{H}, \mathrm{I}_{R \cdot F}=8 \mathrm{Amp}$. の放電条件で励 起し, V 3184.0A/Co 3072.3A, Ni 3461.7A/Co3417.2A (Natural Clay), Ni 3619.4 A/Co 3419.3 A (Synthetic Clay)などを用いて分析している。この場合の標準偏差 率をみると，例えば Synthetic Clay の Niについては 分光分析 $3.3 \%$, 化学分析 (ヂメチルグリオキシムによ る比色）で 6.1\%, Natural Clay 3 種の V については, 分光分析 $6.3 \%, 5.7 \%, 2.5 \%$ 飞対し，化学分析 $13.0 \%$, $2.1 \%, 9.0 \%$ となつて就り, 大部分分光分析の精度が寧 万化学分析它上迴つている.

触媒分析の場合も，標準試料の作製は重大な問題であ る. 完全な湿式混合法105) としては, 新触媒を $539^{\circ} \mathrm{C} 4 \mathrm{hrs}$ 焼いたものに, $\mathrm{Na}$ は $\mathrm{NaCl}$ または $\mathrm{Na}_{2} \mathrm{SO}_{4}, \mathrm{~V}$ は $\mathrm{NH}_{4} \mathrm{VO}_{3}, \mathrm{Fe}, \mathrm{Ni}, \mathrm{Cr}, \mathrm{Ca}$ 注硝酸塩の形で水溶液とし て衫り, 乾固してから更に $539^{\circ} \mathrm{C} 8 \mathrm{hrs}$ 焼いて作る. Burdett ら ${ }^{110}$ は, 使用触媒について Fe throline による比他で, V 它溶液中干渉物除去の後ポー ラログラフにより, Naを Na-zinc uranyl acetate として 求め,これにより検量線学作り, $\mathrm{Cu}, \mathrm{Ni}, \mathrm{Cr}$ 媇触媒の湿 式混合により別に標準を作つている， Cu， Ni は金属を 稀硝酸にとかし， Cr 注 $\mathrm{K}_{2} \mathrm{Cr}_{2} \mathrm{O}_{7}$ 安水にとかして使用し ている. Harmon および Russell の方法111) は固体混合 である. Fe, Na は $1.0 \%, \mathrm{~V}, \mathrm{Ni}$ は 0.05\%のものを作 り，これを順次稀积している。物理的な意味での混合は 湿式法がよいだろうが，硝酸塩䘮焼いて酸化物とすると き，Vあたりが散逸しないような注意が必要であろう。

以上の発光分光分析で $\mathrm{Na}$ も求められるが，触媒の湿 式分析の一環として, 溶液中の Na 分分析するには炎光 光度法がよいだろう. American Cyanamid 社の方法113)

112) C.W. Key and G.D. Hoggan, Anal. Chem. 24, 1921 (1952).

113) American Cyanamid Company, Test Method for Synthetic Cracking Catalyst, p. 43.
はこれである. $\mathrm{Al}_{2} \mathrm{O}_{3}$ 中の $\mathrm{Na}$ の炎光分析における $\mathrm{Fe}$ (III), $\mathrm{Ca}(\mathrm{II}), \mathrm{Ti}$ (II), $\mathrm{Si}$ (II), $\mathrm{Al}$ (III), $\mathrm{Li}$ (I) の干渉 については検討されている114).

\section{2 プラットフォーミング触媒}

プラットフォーミングの触媒は，アルミナをベースと し $0.3-0.6 \%$ の $\mathrm{Pt}$ と $0.1 \%$ のクロライドないしフロ ライドを含す：この場合の触媒毒はチャージ中の As と $\mathrm{Pb}$ である. As は使用原油に含まれる場合だけが問題と なるが，微量でも存在すると（普通はナフサ中にほとえ どないが $350 \mathrm{ppb}$ 検出されている例もある） Pt と定量 的に反応してしまうので必ず除去せ敢济ならないとされ る。また $\mathrm{Cu}, \mathrm{Na}, \mathrm{Hg}$ も有害といわれれている。

改質触媒の分析法に関する資料汪きわめてそしい，触 媒についての報告で㴽なが，チャージナフサの灰を $\mathrm{KCl}$ のバッフォーと炭素粉末と学混じ, $6 \mathrm{Amp}$.のアーク をとばし，As 2288.12 A/Background で分析した例115〉 がある、この場合には，兏化前にトリフェニール砒素を 用いて標準とし， $\pm 20 \%$ の誤差内で分析出来たという. しかし, 触媒自身の分析も左程困難なものではない。試 料調製它工夫することにより，10％程度の標準偏差率 で $\mathrm{Fe}, \mathrm{As}, \mathrm{Pb}$ 安分析することは可能である116)。 またこ の場合には，成型触媒なので，サンプリングの簓所によ。 る分析值のばらつきを考慮しておかなけ机ばならない。

\section{6. 実用化の現状と方向}

いま石油工業の金属成分分析について主なる 10 項目 を選び，それについて実用価値の大きな方法を分類列挙 したものが Table 10 である。

内容の詳細な説明沙省略するが, 概していえることは, (1) F.C.C. 触媒, プラットフォーミング触媒およびガソ リンの分析は, 現在でも分光分析の実用価值が大きい, ということと（2）燃料油や，潤滑油の 新油および使用 油注, 高性能の発光装置, 光源, 格子分光器などの機器 設備の有無によつて事情が異なるが，設倩があれば，分 光分析による迅速定量法の力が実用上有利である，とい うことであろう。

これまでの具体例によつても, 発光分光分析の特長は, 定性分析と迅速定量といら点にあることが明かである. したがつて, 石油兏分, スラッジ，デポジットなどは， 万能の方法による多元素半定量法汃有益である。石油類

114) L. Braicovich and M.F. Landi, Met. ital., 49, 465 (1957).

115) F. Wagner und R. Vitt, Erdöl und Kohle, 7, 460 (1958).

116）未発表（出光社内報告 AR-6, Feb. 15, 1960)。 
Table 10. 石油工業に打ける実用金属分析法

\begin{tabular}{|c|c|c|c|}
\hline & \multirow{2}{*}{ 試料 } & \multirow[t]{2}{*}{ 分 析 元 } & 分 析 \\
\hline & & & そ の 他 の \\
\hline 1 & 原 油・ & 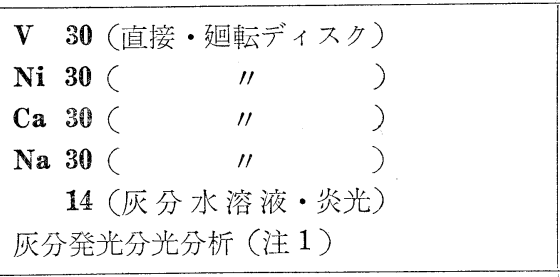 & 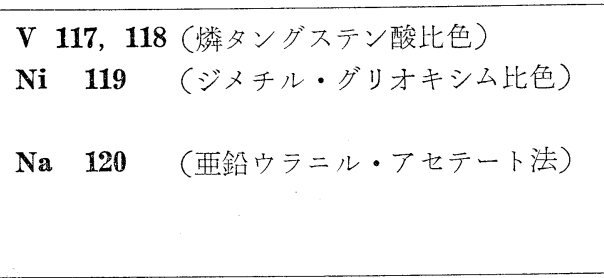 \\
\hline 2 & $\begin{array}{ll}\mathrm{FCC} & \text { 張 } \\
\text { 运 油 }\end{array}$ & 灰分発光分光分析（注 1) & $\begin{array}{ll}\mathrm{Fe} & \mathbf{1 2 1} \text { (2.2'-ジピリジル比色) } \\
\mathrm{V} & \mathbf{1 2 1} \text { (ジフェニル・ベンチジン比色) } \\
& \mathbf{1 2 2} \text { (ポルフィリン錯塩吸収, 抽出) } \\
\mathrm{Ni} & \mathbf{1 2 1} \text { (ジメチル・グリオキシム比色) }\end{array}$ \\
\hline 3 & 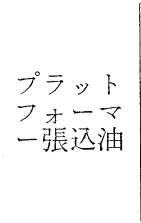 & 灰分発光分析（注 1 ) & $\begin{array}{ll}\text { Fe } & 123 \text { (フェナンスロリン比色) } \\
\text { As } & 124 \text { (U.O.P-グッツアイト法) } \\
& 125 \text { (Ag-DDTC 比色) } \\
\text { Pb } & 126,127 \text { (ジチゾン比色) } \\
\text { Hg } 128 \text { (ジチゾン比色) }\end{array}$ \\
\hline 4 & ガソリン & $\begin{array}{l}\text { Pb } 56 \text { (直接・炎光 }) \\
\text { Mn } 59 \text { (直接・炎光 }) \\
\text { P } 60 \text { (直接・廻転ディスク })\end{array}$ & $\begin{array}{l}\mathrm{Pb} \quad 57 \text { (抽出重量) } \\
\quad 58 \text { (抽出ポーラロ) } \\
\mathrm{Mn} 129 \\
\mathrm{P} \quad \mathbf{1 3 0} \text { (モリブドバナド燐酸比色) } \\
\quad \mathbf{1 3 1} \text { (モリブデンブルー比色) }\end{array}$ \\
\hline 5 & $\begin{array}{l}\text { 潤 滑 油 } \\
\text { （新 油） }\end{array}$ & 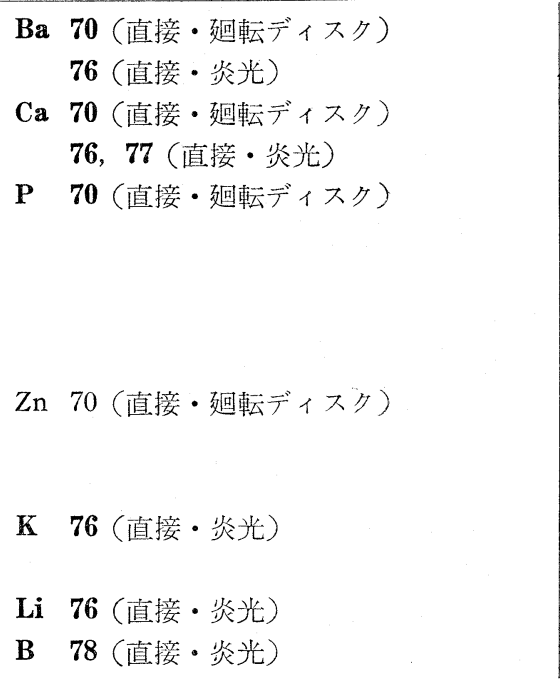 & 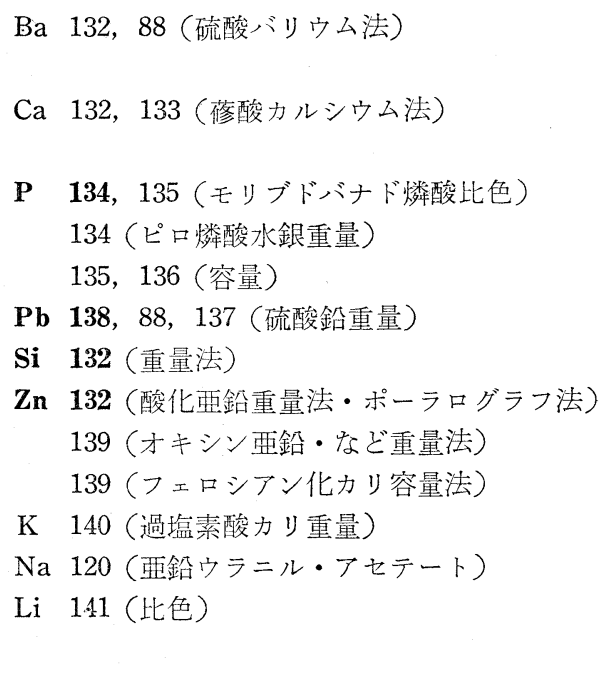 \\
\hline & & $\begin{array}{ll}\mathrm{Fe} & 19 \text { (直接・廻転ディスク) } \\
& 95 \text { (直接・迴転プラット・中型プリズム) } \\
\mathrm{Si} & 19 \text { (廻転ディスク) } \\
& 95 \text { (迴転プラット・中型) } \\
\mathrm{Pb} & 19 \text { (廻転ディスク) }\end{array}$ & $\begin{array}{ll}\mathrm{Fe} & 138 \text { (o-フェナンスロリン比色) } \\
& 137 \text { (チオグリコール酸比色) } \\
\mathrm{Si} & 132 \text { (重量) } \\
& \\
\mathrm{Pb} & \mathbf{1 3 8}, 88,137 \text { (硫酸鉛重量) }\end{array}$ \\
\hline
\end{tabular}




\begin{tabular}{|c|c|c|c|}
\hline 6 & $\begin{array}{l}\text { 使 用 潤 } \\
\text { 滑 油 }\end{array}$ & $\begin{array}{ll} & 95 \text { (廻転プラット・中型) } \\
\mathrm{Cr} & 19 \text { (迴転ディスク) } \\
& 95 \text { (廻転プラット・中型) } \\
\mathrm{Al} & 19 \text { (廻転ディスク) } \\
& 95 \text { (廻転プラット・中型) } \\
\mathrm{Cu} & 19 \text { (廻転ディスク) } \\
& 95 \text { (廻転プラット・中型) } \\
\text { B } & 19 \text { (廻転ディスク) } \\
& 95 \text { (廻転プラット・中型) } \\
\text { Ag } & 19 \text { (廻転ディスク) }\end{array}$ & $\begin{array}{l}\text { Cr } 142 \text { (ジフェニル・カルハシジット比色) } \\
\text { Al } 132 \text { (重量法) } \\
\text { Cu 138, } 137 \text { (DDTC 比色) }\end{array}$ \\
\hline 7 & FCC 触媒 & $\begin{array}{lllll}\mathrm{Fe} & 105 \text { (注 2) } & \text { (粉末アーク) } \\
\mathrm{V} & 105 & ( & \prime \prime & ) \\
\mathrm{Ni} & 105 & ( & \prime \prime & ) \\
\mathrm{Cu} & & & & \\
\mathrm{Cr} & 105 & ( & \prime \prime & ) \\
\mathrm{Na} & 105 & ( & \prime & ) \\
\mathrm{Ca} & 105 & ( & \prime & )\end{array}$ & $\begin{array}{ll}\mathrm{Fe} & 143 \text { (○-フェナンスロリン比色) } \\
\mathrm{V} & 145 \text { (比色) } \\
\mathrm{Ni} & 144 \text { (比色) } \\
\mathrm{Cu} & 146 \text { (比色) } \\
\mathrm{Na} & 147 \text { (ウラニル比色) }\end{array}$ \\
\hline 8 & $\begin{array}{l}\text { プラット } \\
\text { フォォミミ令触媒 }\end{array}$ & $\begin{array}{ll}\text { Fe } & 116 \text { (粉末アーク) } \\
\text { As } & 116(1 " \prime) \\
\operatorname{Pb} & 116(1 " \prime)\end{array}$ & 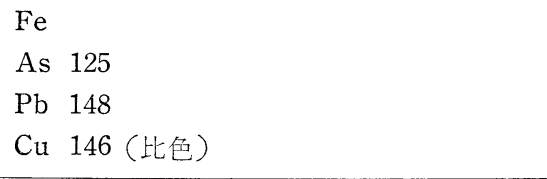 \\
\hline 9 & $\begin{array}{l}\text { 各種スラ } \\
\text { ジ・デ } \\
\text { ポジット }\end{array}$ & 発光分光分析（注 1) & $\begin{array}{ll}\mathrm{Pb} & 149 \text { (クロム酸鉛) } 150 \\
& \text { (キレート) } 151 \text { (ポーラロ }) \\
\mathrm{Ba} & 152 \text { (硫酸バリウム) } \\
\mathrm{Si} & 152 \text { (シリケート類として) } \\
\mathrm{Cu} & 153 \text { (チオ硫酸ソーダ容量) } \\
\mathrm{Fe} & 154 \text { (重クロム酸カリ容量) } \\
\text { その他 } \\
\mathrm{Br}, \mathrm{Cl} 156 \\
\mathrm{SO}_{4} \quad 156 \\
\mathrm{~S}^{157,} 158 \text { (Ba 含すとき) } \\
\mathrm{PO}_{4} 159\end{array}$ \\
\hline 10 & $\begin{array}{l}\text { ボイラー } \\
\text { スケール, } \\
\text { 腐食物 } \\
\text { ○ 他 }\end{array}$ & 発光分光分析（注 1） & 各種テスト（注 3 ） \\
\hline
\end{tabular}

太字注実用性大なるを示す. 数字以交献番号.

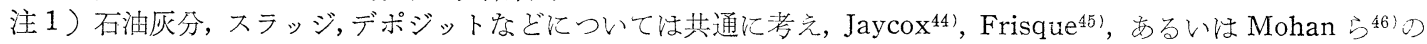
ように高度のバッフォーを用いる普偏的な方法がよい。

2）FCC 触媒に対する Gunn の方法1051 注大体簡単でよいが，分光用試料調製法定幾分改良すべきであるう。

3 ）試料の種類が多いので一般的なことはいえないが, 多くの場合, 分光分析のほか枃熱減量, 硫黄, 八曰ゲン などが必要である。

117) ASTM D 1548-58 T, p. 865 (1958).

118) Ibid, D 1548-59 T, p. 869 (1959).

119) E. B. Sandell, "Colorimetric Determination of Traces of Metals" p. 665 (1959).

120) Ibid, p. 821 (1959).
121) F.M. Wrightson, Anal. Chem., 21, 1543(1949).

122）原 明, 山崎秀男, 石油誌, 3, 311 (1960).

123) E.B. Sandell "Colorimetric Determination of Traces of Metals", p. 522 (1959).

124) UOP Method 296-58, p. 325 (1959). 
の定量を目ざすときには，直接法かせいぜいコークス化 法の範囲で迅速性に心染けるべきである.

また実際分析者の立場から気付いたネック 3 つを述べ ておこう、第一㭠にも触れた分光分析装置の問題であ る. 通覧し来つた交献の大部分は格子分光器, マルチソ 一ス, 直流高压スパーク, 気密光源装置, グラファイト 趈転ディスクなどを使用しているが，我国の現状では設 備や材料の関係でこ礼らの条件を再現することが困難 で，実用価值として交献があをり利用出来ない，第二は 標準試料の問題である. 従来とかく軽視されがちである

125) D. Liederman, J.E. Bowen and O.I. Milner, Anal. Chem., 31, 2052 (1959).

126) ASTM D $1368-58 \mathrm{~T}$, p. 796 (1959).

127) UOP Method, 350-58, p. 455 (1959).

128) E.B. Sandell "Colorimetric Determination of Traces of Metals", p. 621 (1959).

129) Ibid, p. 606 (1959).

130) EAM Serial No. OP 58/5 A-2 (1958).

131) UOP Method, 353-58, p. 473 (1959).

132) ASTM D 811-48, p. 330 (1959);D 1549-58 T, p. 874 (1959).

133) IP (The Institute of Petroleum), 111/49 T, p. 111 (1959).

134) ASTM D 1091-58 T, p. 564 (1959).

135) IP (The Institute of Petroleum), 148/58, p. 414 (1959).

136) IP (The Institute of Petroleum), 149/58, p. 424 (1959).

137) IP (The Institute of Petroleum), 120/48, p. 314 (1959).

138) ASTM D 810-59, p. 322 (1959).

139) IP (The Institute of Petroleum) 117/53 T, p. 755 (1959).
が，調製法と調製品の検定法について一層の研究が必要 であり，各種の規格品が市販されるようになることを希 望したい. 最後は光源部の問題である. 粉末試料と油試 料它分析しようとする度に光源部を組变えるのは厄介で あり, 光源部は組んだままで光学系を共通とするような 方式が工夫されれば実益は大きい。

さて, 結局発光スペクトルは害用的な定量分析法にな るであろうか.このような疑問を起こさせないように， 石油工業の問題についても分光分析法の規格化への努力 が続けられなければならないであろら。

140) E. B. Sandell "Colorimetric Determination of Traces of Metals ', p. 733 (1959).

141) Ibid, p. 584 (1959).

142) Ibid, p. 388 (1959).

143) UOP Method 340-59 p. 431 (1959).

144) A. T. Blackwell and A. M. Daniel, Anal. Chem., 28, 1209 (1956).

145) E. B. Sandell, "Colorimetric Determination. of Traces of Metals", p. 923 (1959).

146) Ibid, p. 437 (1959).

147) Ibid, p. 821 (1959).

148) Ibid, p. 555 (1959).

149) EAM Serial No. OP 58/5 B2 (a) (1958).

150) Ibid, B2 (b) (1958).

151) Ibid, B2 (c) (1958).

152) Ibid, B3 (1958).

153) Ibid, B4 (1958).

154) Ibid, B5 (1958).

155) Ibid, B7 (1958).

156) Ibid, B8 (1958).

157) Ibid, B9 (a) (1958).

158) Ibid, B9 (b) (1958).

159) Ibid, B11 (1958). 